Omówienia 



\section{Marta Tomczok}

Uniwersytet Śląski, Wydział Filologiczny, Instytut Nauk o Literaturze Polskiej orcid.org/0000-0001-9512-007X

marta.tomczok@us.edu.pl

\section{Religijny kicz holokaustowy. Zarys zjawiska}

\section{Pojęcie}

Istota religijnego kiczu holokaustowego tkwi w przekonaniu o wzajemnym pokrewieństwie nazizmu i retoryki Kościoła katolickiego. Oddziaływanie mistyki chrześcijańskiej na wypowiedzi Hitlera i jego wyznawców zostało dokładnie przeanalizowane w LTI. Notatniku filologa Victora Klemperera, stając się jedną z najważniejszych cech lingua tertii imperii. „To, że LTI w swoich punktach kulminacyjnych musi być językiem wiary, rozumie się samo przez się, bo przecież nastawia się na fanatyzm. Ale znamienne jest przy tym, że jako język wiary opiera się ściśle na chrześcijaństwie, dokładniej mówiąc, na katolicyzmie, jakkolwiek narodowy socjalizm to jawnie, to skrycie, to teoretycznie, to znów praktycznie od samego początku zwalcza chrześcijaństwo, a zwłaszcza Kościół katolicki”¹.

Niejednoznaczność, wpisana w naturę tych relacji, zbliża je do zawiłej struktury kiczu. W artykule sprzed czterdziestu czterech lat Paweł Beylin stwierdził: „Kicz jest pojęciem nieokreślonym, wieloznacznym, używanym niemal intuicyjnie, a przy tym wartościującym"2. Od tego czasu niewiele zmieniło się w jego rozumieniu. Uporządkowanie wiedzy na temat kiczu w ogóle, a kiczu holokaustowego w szczególności, wymagałoby wysiłku Herkulesa, „aby oczyścił tę istną stajnię Augiasza z wieloznaczności i wprowadził ład pojęciowy do wielopiętrowej struktury wartościowania estetycznego, w której na każdym szczeblu występuje wieloznaczność" ${ }^{3}$. Połączenie obu tak wyraźnie niejednoznacznych zjawisk jak relacja nazizmu i chrześcijaństwa z jednej strony oraz zastosowanie kiczu do badań dyskursu o nazizmie, a zwłaszcza Zagładzie, z drugiej ${ }^{4} \mathrm{z}$ dużym

${ }^{1}$ Victor Klemperer, LTI. Notatnik filologa, tłum. Juliusz Zychowicz, Warszawa: Aletheia, 2014, s. 114.

${ }^{2}$ Paweł Beylin, Kicz jako zjawisko estetyczne i pozaestetyczne [w:] idem, Autentyczność i kicze, Warszawa: PIW, 1975, s. 179.

${ }^{3}$ Ibidem, s. 180.

${ }^{4} \mathrm{O}$ kiczu jako idei i wynikających stąd konsekwencjach dla badań zjawiska zob. Herman Broch, Kilka uwag o kiczu (Odczyt), tłum. Danuta Borkowska, Jan Garewicz, Ryszard Turczyn, Warszawa: Czytelnik, 1998, s. 103. 
prawdopodobieństwem może skutkować powstaniem terminu o zbyt wysokim stopniu niejasności, aby mógł on dobrze opisywać nadużycia w literaturze na temat Holokaustu.

Jeszcze innym czynnikiem powodującym, że religijny kicz holokaustowy nie daje się skodyfikować, jest panujące wśród badaczy przekonanie o niestosowności formułowania wniosków na temat teologii, którą Stanisław Obirek określił mianem Auschwitz - Golgoty naszych czasów ${ }^{5}$, nadmieniając przy tym, że dla niego jako myśliciela w szczególny sposób uwikłanego w oddziaływanie tego typu refleksji „problem obecności Boga w Holokauście okazywał się [przy każdej okazji - M.T.] nad wyraz trudny"6. Jeśli doda się do tego, że z prowadzonych m.in. w takich ośrodkach jak Oksford, Londyn czy Leeds studiów nad popkulturą i Zagładą ${ }^{7}$ prawie zupełnie zniknęło pojęcie kiczu, należy przyjąć, że oprócz tego, iż od lat jest ono zbyt wieloznaczne, przestało być także aktualne, a w jakimś sensie też operacyjne i modne.

W pracy Refleksy nazizmu. Esej o kiczu i śmierci Saula Friedländera, która mimo upływu czasu nie straciła walorów poznawczych, pojawia się zdanie niepokojąco nieprawdziwe i wymagające nie tylko komentarza, ale przede wszystkim opatrzonej uzasadnieniem korekty: „Dziś warunki socjoekonomiczne niezbędne do pojawienia się zjawiska pokrewnego nazizmowi nie istnieją, a ewolucja polityczna Zachodu w najmniejszym stopniu nie przypomina tej, która miała miejsce w międzywojennej Europie"8. Po prawie czterdziestu latach od wydania wspomnianej książki sytuacja na starym kontynencie tak bardzo się zmieniła, że przytoczona opinia - gdyby dodać do niej odpowiednie zaprzeczenia - mogłaby uchodzić za jedno z najbardziej aktualnych (i złowieszczych) stwierdzeń Friedländera. Ponieważ odnosi się ono w przeważającej mierze do warunków, w jakich powstawał nazizm, a wraz z nim, częściowo opisany przez Klemperera, dyskurs nazistowski, warto się zastanowić, w jakim stopniu możliwe jest uwspółcześnienie pojęć zaproponowanych przez autora Czasu eksterminacji do oceny nastrojów społecznych, z którymi łączy się pojęcie kiczu.

Gdyby chcieć kicz traktować przede wszystkim jako przejaw szczególnego rodzaju komunikowania się społeczeństwa w sprawie jego oczekiwań i pragnień związanych z tym, w jaki sposób powinna być prowadzona współczesna polityka państw europejskich (w tym zwłaszcza Polski) wobec Zagłady, należałoby zobaczyć $w$ nim poręczne narzędzie do zbierania informacji o fantazjach i lękach współczesności, a odrzucić z kolei wszystkie narosłe wokół tego zjawiska przez

${ }^{5}$ Stanisław Obirek, Holokaust - problem Boga czy człowieka? [w:] Holokaust a teodycea, red. Jerzy Diatłowicki, Karolina Rąb, Iwona Sobieraj, Kraków: Wydawnictwo Homini, 2008, s. 60.

${ }^{6}$ Ibidem.

${ }^{7}$ Chodzi przede wszystkim o prace Gillian Rose, Roberta Eaglestone'a i Matthew Boswella, o których mowa będzie w dalszej części artykułu.

${ }^{8}$ Saul Friedländer, Refleksy nazizmu. Esej o kiczu i śmierci, tłum. Marcin Szuster, wstęp Paweł Śpiewak, Warszawa: WUW, 2011, s. 31-32. 
lata wątpliwości, zwłaszcza te, które wiążą się z jego strukturą, dyfuzją etyki i estetyki czy z intuicyjnym charakterem kiczu, w zasadzie wykluczającym go z obiegu terminów naukowych.

Religijny kicz holokaustowy w przyjętym tu rozumieniu oznacza retorykę sprawców i współsprawców Zagłady, w celach zbrodniczych wykorzystującą język religii do stworzenia narracji przypisującej wspomniane sprawstwo Bogu bądź jego nieobecności (brakowi) ${ }^{9}$. Religijny kicz holokaustowy można także utożsamiać z wszelkiego typu refleksją artystyczną i akademicką, która za pomocą środków, o jakich pisał Klemperer, z „gładko i nieświadomie przyswajalną mistyką" ${ }^{10}$ na czele, utrwala fałszywe przekonania teologów o możliwości „oswojenia” Auschwitz, korzystając z pośrednictwa wyszukanych, biblijnych metafor i porównań, takich jak wspomniana „Golgota” czy „drugi Synaj”11. Abraham J. Heschel nazwał tego typu myślenie „największym bluźnierstwem [...] urągającym Bogu”12, a Obirek przyznał kategorycznie: „Holokaust to problem i dzieło człowieka. Wszelkie próby włączenia weń Boga są chybione"13. W najbardziej współczesnym sensie religijnym kiczem holokaustowym będą te wszystkie przejawy kultury, sztuki i literatury, w których dochodzi do manifestacji zagładowej pobożności (termin Gillian Rose) polegającej na uświęcaniu roli ofiar, podkreślaniu sprawiedliwości Sprawiedliwych i poszukiwaniu scenariuszy pozwalających zrozumieć zbawczy sens Zagłady.

W proponowanej tu koncepcji kicz nie służy zadowalaniu mas, tworzeniu fałszywego obrazu świata na zamówienie odbiorcy popkultury, nie jest też szmirą, podróbką czy synonimem nieautetyczności. Jest natomiast świadomie stosowanym narzędziem określonej ideologii, z czym wiąże się znacznie większa niż się przyjmuje sprawczość adresata kiczowatego dzieła. W procesie kreowania kiczu staje się on kimś więcej niż tylko bezwolnym, dającym się zaspokajać konsumentem. Także twórca kiczu nie powinien być identyfikowany z kimś spełniającym zachcianki mas i działającym wyłącznie na społeczne zamówienie ${ }^{14}$.

${ }^{9}$ Warto w tym miejscu przypomnieć ważną uwagę Aleksandry Ubertowskiej: „efekt kiczu jest w jakiś niejasny, trudny do uchwycenia sposób powiązany z opowiadaniem o Holokauście z perspektywy sprawcy, z manipulowaniem wokół etycznie doniosłego sensu «trójkąta Hilbergowskiego» (sprawca - ofiara - świadek)" (Aleksandra Ubertowska, Krzepiaca moc kiczu. Literatura Holokaustu na (estetycznych) manowcach, „Zagłada Żydów. Studia i Materiały” 2010, nr 6, s. 30).

${ }^{10}$ Klemperer, LTI..., s. 121.

${ }^{11} \mathrm{Na}$ temat koncepcji Emila Fackenheima i teologów chrześcijańskich zob. wspomniany artykuł Obirka.

${ }^{12}$ Obirek, Holokaust..., s. 79.

${ }^{13}$ Ibidem.

${ }^{14}$ Pisała o tym Gabriela Żuchowska: „Satysfakcja estetyczna odbiorcy dominuje nad dotychczasowym przywilejem artysty czy profesjonalnych krytyków w zakresie kształtowania powszechnej recepcji dzieła" (Gabriela Żuchowska, Kicz - przegląd koncepcji teoretycznych i propozycja definicji do celów badawczych, „Kultura i Społeczeństwo” 2013, nr 1, s. 134). 
W przypadkach, o jakich będzie dalej mowa, pisarze tacy jak Zbigniew Białas czy Wojciech Dutka zdają się dokładnie znać cel wytwarzania religijnego kiczu holokaustowego i sugerują jego związki z ideologią Kościoła katolickiego w Polsce, chrystianizacją Zagłady bądź przemocą filosemicką.

Opisane wyżej przewartościowanie, prowadzące do wniosku, że kiczem nie rządzi potrzeba spełnienia gustu „kitsch-mana"15, lecz opisuje go zbiór określonych zasad estetyczno-politycznych, zmierzających w przypadku Zagłady do zafałszowań historycznych i manipulacji pojęciem sprawstwa, powoduje, że warto przemyśleć to zjawisko w kategoriach nowoczesnego narzędzia zdolnego odkrywać społeczne antagonizmy, nastroje ludobójcze, nastawienie do polityki historycznej, politykę antyuchodźczą, antysemickie fantazje czy wreszcie skrajny nacjonalizm. Należy przy tym pamiętać, że kicz holokaustowy posługuje się łagodną retoryką w celu zastosowania przemocy. Jest przykładem „Gemütlichkeit, zjawiska «uprzytulniania» świata” ${ }^{16}$, w którym dominuje okrucieństwo. Ów rozziew, niejedyny zresztą, stanowi źródło struktury analizowanego zjawiska.

\section{Koncepcje}

Podstawę opisu i zrozumienia religijnego kiczu holokaustowego stanowi XVIII rozdział LTI, zatytułowany Wierzę $w$ niego. Przedmiotem analizy Klemperera są w nim przykłady bezgranicznego, fanatycznego i pełnego emfazy zachwytu Hitlerem w czasach Trzeciej Rzeszy oraz jego wypowiedzi o sobie samym. Z omawianym tu zjawiskiem łączą się one przede wszystkim w punkcie, który można określić jako sposób osiągania i wytwarzania tego zachwytu. Autor notatnika próbuje go oddać zaledwie w kilku, ale jakże wymownych, zdaniach:

Cały sztafaż słowny działa jednak w kierunku transcendencji chrześcijańskiej: mistyka świętej nocy, męczeństwo, zmartwychwstanie, zakon rycerski wiążą się (wbrew swej pogańskiej intencji) jako wyobrażenia katolickie czy, że tak powiem, parsifalowskie, z czynami Führera i jego partii ${ }^{17}$.

Religijna kulminacja tego działania polega więc na konkretnych, chrystologicznych zwrotach, a następnie, i to w stopniu silniejszym, na wypowiadaniu znacznych partii mowy w sposób kaznodziejski i z silną emfazą ${ }^{18}$.

Rozmaite wyrażenia i zwroty LTI zatrącające o transcendencję tworzą wspólnie sieć, która zarzucona na wyobraźnię słuchacza, przeciąga ją w stronę wiary. Czy sieć ta jest świadomie wiązana, czy polega, by użyć osiemnastowiecznego określenia, na kapłańskim oszustwie? Po części zapewne tak. Nie należy

${ }^{15}$ Paweł Śpiewak, Kicz i estetyzacja polityki [w:] Saul Friedländer, Refleksy nazizmu..., s. $12-13$.

${ }^{16}$ Żuchowska, Kicz..., s. 140.

${ }^{17}$ Klemperer, LTI..., s. 115.

${ }^{18}$ Ibidem, s. 117. 
zapominać, że u niektórych inicjatorów doktryny niewątpliwie istotną rolę grała potrzeba wiary i religijna gotowość ${ }^{19}$.

[...] nazizm był przez miliony przyjmowany jako ewangelia, bo posługiwał się językiem Ewangelii ${ }^{20}$.

Analiza tych stwierdzeń prowadzi do wniosku, że stosowanie przez Hitlera i jego wyznawców aluzji do retoryki katolickiej w jej najbardziej mętnej, mistycznej odmianie, całkowicie skompromitowało i uniemożliwiło stosowanie tego typu języka w dyskursie powojennym. Jak wykazał Friedländer, przesiąknięta romantyczną estetyką wyobraźnia nazistów sama w sobie pełna była skostniałych i fałszywych wyobrażeń, tożsamych z pojęciem kiczu ${ }^{21}$. Wydaje się jednak, że nowe źródło wspomnianych zafałszowań, na jakie wskazał Klemperer, nie utrwaliło się w świadomości powojennej krytyki w takim stopniu, jak analizy Friedländera. Mogło się stać nawet odwrotnie: ze względu na katolicki rodowód nazistowskiego kiczu, znacznie bardziej niebezpieczny dla wielu środowisk z Kościołem na czele, uległo ono zaplanowanemu zatarciu i zapomnieniu.

Tymczasem rozważania na temat zawartej w religijnym kiczu holokaustowym ideologii należy rozpocząć od stwierdzenia jego silnych, nierozerwalnych więzi z „ewangelicznym” wymiarem nazistowskiej retoryki. Wszystkie pozostałe koncepcje, późniejsze od zapisków Klemperera, są wobec jego intuicji nie tylko wtórne, ale przede wszystkim łagodniejsze i słabsze, co wynika po części ze wspomnianego procesu zapominania.

Jak zauważa Gillian Rose w pracy Mourning Becomes the Law. Philosophy and Representation, powojenna cywilizacja śmierci stała się jednocześnie cywilizacją kiczu ${ }^{22}$. Na związki nazizmu z kiczem i śmiercią zwracał także uwagę Friedländer, odwołując się do tych samych co autor LTI sposobów osiągania estetycznej emfazy, przede wszystkim pokazując, że fascynacja społeczeństwa powojennego zjawiskiem śmierci jest zapośredniczona w jego nieuregulowanym, nierozliczonym stosunku do polityki Hitlera. Z kolei przyczyną tego miała być, według Ernsta Brocha, kiczowata atmosfera niezdrowej nekrofilii, którą nazizm znajdował w literaturze romantycznej ${ }^{23}$. Do podobnych wniosków doszedł Daniel Tiffany, omawiając kicz w poemacie Ezry Pounda Cantos. Kicz śmierci miał być, według niego, kiczem zniszczenia, apokalipsy, nieintegrującym się ze zwyczajnym, pospolitym, mówiąc słowami Beylina: „jarmarcznym”, kiczem²4.

\footnotetext{
${ }^{19}$ Ibidem, s. 122 .

${ }^{20}$ Ibidem.

${ }^{21} \mathrm{Na}$ temat relacji kiczu z romantyzmem, a szczególnie z balladą romantyczną zob. Daniel Tiffany, My Silver Planet. A Secret History of Poetry and Kitsch, Baltimore: Johns Hopkins University Press, 2014, s. 134-168.

${ }^{22}$ Gillian Rose, Mourning Becomes the Law. Philosophy and Representation, Cambridge: Cambridge University Press, 1996.

${ }^{23}$ Tiffany, My Silver Planet..., s. 147.

${ }^{24}$ Ibidem, s. 148.
} 
Wprowadzony przez Rose termin „holokaustowa pobożnośc” (Holocaust piety), zdaniem Matthew Boswella, jest bardzo rozpowszechniony wśród badaczy Zagłady i innych ludobójstw. „Identyfikuje [on - M.T.] ludzki i metafizyczny optymizm, który kryje się za pewnymi formami odkupienia"25. W rzeczywistości, tworząc go, Rose nawiązała do dyskusji wokół Listy Schindlera Stevena Spielberga oraz opinii krytyka Bryana Cheyette'a, w którego opinii myśl przewodnia filmu („kto ratuje jednego człowieka, ratuje cały świat”), została przez reżysera pozbawiona kontekstu i opacznie zinterpretowana. Jej źródłem miał być Talmud, a zacytowane zdanie - według Rose - należało potraktować jako najbardziej ironiczny, święty komentarz w dziejach literatury światowej ${ }^{26}$.

Rose nadała „holokaustowej pobożności” jeszcze jedno znaczenie, łącząc je z mistyką, towarzyszącą tabu reprezentacji (bezkarnie naruszonemu we wspomnianym filmie podczas słynnej sceny w krematorium, gdzie zamiast gazu zostaje puszczona na uwięzionych woda). Zdaniem filozofki większym problemem wydaje się przywiązanie do myśli o konieczności nadania faszyzmowi jakiejkolwiek reprezentacji. Tymczasem jest wręcz przeciwnie: „argument za przezwyciężeniem reprezentacji, w jej estetycznej, filozoficznej i politycznej wersji, zbiega się z wewnętrzną tendencją samego faszyzmu"27.

Jak wynika z rozważań na temat rozdziału XVIII LTI, faszyzm może nie mieć jednoznacznej reprezentacji. Uczynienie z retoryki katolickiej sposobu na jego wysłowienie - jeśli czytać konsekwentnie wykład Rose - wydaje się bliższe myśli postmodernistów o niewyrażalności Zagłady. Wszystko to oznacza, że religijny kicz holokaustowy jest zjawiskiem pozbawionym jednoznacznej intencji i wymowy, a jego podstawę stanowi dobrze zamaskowna, zbrodnicza ideologia.

Syntetycznego opracowania kiczu postholokaustowego i holokaustowej pobożności dokonał Robert Eaglestone, który w pracy The Broken Voice. Reading post-Holocaust Literature zaproponował analizę dwu tekstów kultury: znanej powieści Johna Boyne’a Chłopiec w pasiastej piżamie ${ }^{28}$ oraz rzeźby-instalacji Hell Jake'a i Dinosa Chapmanów. Odwołując się do koncepcji kiczu Lisy Saltzman i kategorii bycia uroczym (cute) Sianne $\mathrm{Ngai}^{29}$, badacz podkreślił, że kicz holokaustowy jest zgoła czym innym, „oznacza to, co oddziela świat Holokaustu od naszego świata w samym akcie reprezentowania Holokaustu" ${ }^{30}$.

${ }^{25}$ Matthew Boswell, Holocaust Impiety in Literature, Popular Music and Film, London: Palgrave Macmillan, 2012, s. 1.

${ }^{26}$ Rose, Mourning Becomes..., s. 46.

${ }^{27}$ Ibidem, s. 41.

${ }^{28} \mathrm{Na}$ ten temat zob. ciekawą analizę Aleksandry Ubertowskiej Krzepiąca moc kiczu...

${ }^{29}$ Lisa Saltzman, „Avant-Garde and Kitsch Revisited” [w:] Mirroring Evil: Nazi Imagery/Recent Art, red. Norman Kleeblatt, New York: The Jewish Museum i New Brunswick-Rutgers University Press, 2001, s. 55; Sianne Ngai, Our Aesthetic Categories: Zany, Cute, Interesting, Harvard: Harvard University Press, 2012.

${ }^{30}$ Robert Eaglestone, The Broken Voice. Reading post-Holocaust Literature, Oxford: Oxford University Press, 2017, s. 141. 
Rzeźba Hell została po raz pierwszy zaprezentowana w 2000 r. w Royal Academy w Londynie. Następnie w 2004 r. spłonęła w pożarze. Została odbudowana i pokazana jako Fucking Hell w 2008 r. w London's White Cube Gallery. W pierwszej wersji przedstawiała miniaturowy, apokaliptyczny świat przypominający sceny z obozów zagłady (przyjazd transportu, palenie ludzi w dołach), zamknięte $\mathrm{w}$ dziewięciu szklanych skrzyniach (osiem z nich miało wymiary: $(182,9 \times$ $121,9 \times 121,9 \mathrm{~cm}$, dziewiąta $-121,9 \times 121,9 \times 121,9 \mathrm{~cm})^{31}$. W komentarzu do drugiej wersji instalacji podkreślano przede wszystkim surrealny charakter wielu scen, makabrę, kanibalizm i obrazy przedstawiające ścięte głowy więźniów, wbite na piki. Miał to być sposób na „egzorcyzmowanie” zachodniej cywilizacji ${ }^{32}$. Eaglestone zwrócił uwagę na przemieszanie w omawianym dziele stylistyk, wśród których zauważył nawiązania do malarstwa Goi, Boscha, swastyki, katolickie krzyże ${ }^{33}$, a nawet podobizny Adama i Ewy czy Stephena Hawkinga. Komentując projekt Chapmanów, badacz podkreślił jego sztuczność, polegającą na odtworzeniu brytyjskiej pamięci Zagłady z filmów, komiksów i kreskówek, a także na eksponowaniu sprawstwa esesmanów i przemilczeniu współudziału w Zagładzie zwyczajnych ludzi ${ }^{34}$.

Hell jako przykład religijnego kiczu holokaustowego może wydawać się dziełem skrajnie nieideologicznym, wyczerpującym swój potencjał jedynie w środkach, takich jak emfaza, patos czy hiperbole. Zdaniem Eaglestone'a niebezpieczeństwo projektu Chapmanów polega jednak na przedstawieniu satanistycznej interpretacji Zagłady, z uwzględnieniem satanizmu samych nazistów, gdzie zło jest w istocie czymś błahym, zabawką dla dzieci, zbiorem figurek, makietą. Nawiązania do Biblii, a zwłaszcza sztuki kościelnej (figurki mężczyzn z powykrzywianymi ze strachu twarzami, makieta przypominająca ruchome szopki itp.), mają na celu jedynie podkreślić nieistotność i błahość makabrycznego przedstawienia. Nie służą natomiast, jak polski kicz religijny, zatajaniu postaw antysemickich społeczeństwa, a nade wszystko wpisywaniu Zagłady w światopogląd katolicki.

Najistotniejszą cechą obu analizowanych przez Eaglestone'a dzieł jest mistyfikacja: Chapmanowie jedynie udają, że tworzą rzeźbę mającą pokazać karę spadającą na sprawców Zagłady; Boyne wytwarza sztuczne poczucie sprawiedliwości, kreując postaci zaprzyjaźnionych chłopców, wymagających od świata, aby zapamiętał ich heroiczne, antyludobójcze postawy. W istocie dużo bliżej prawdy znajduje się określenie wprowadzone przez Boswella, czyli „holokaustowa niepobożność". Dzieła, w których zamiast emfazy i hiperboli stosuje się parodię czy

${ }^{31}$ Ibidem, s. 143 .

${ }^{32}$ Dokładne zdjęcia rzeźby można zobaczyć tutaj: https://www.designboom.com/art/jake-dinos-chapman-fucking-hell-fondazione-prada-sanguine-baroque-10-18-2018/ (dostęp 27 IV 2019 r.).

${ }^{33}$ Eaglestone, The Broken Voice..., s. 144.

${ }^{34}$ Ibidem, s. 147. Zob. także: Yehuda Bauer, Przemyśleć Zagładę, tłum. Jerzy Giebułtowski, Janusz Surewicz, Warszawa: ŻIH, 2016, s. 333. 
ironię, o wiele bardziej angażują się w przekazanie odbiorcy historii niezamazanej przez religię.

Nowy rodzaj kiczu postholokaustowego, twierdzi Eaglestone, zakłada istnienie ekstra kary za ekstra zło. W rzeczywistości akceptujące taki rodzaj myślenia narracje są pseudokatarktyczne. Pobożność, co trzeba podkreślić, nie odnosi się w nich zazwyczaj (wyjątkiem będą tu obie wersje Hell) do źródeł religijności chrześcijańskiej. Opiera się ona przede wszystkim na sentymentalnej wierze w sens cierpienia i wartość przebaczenia. Zupełnie inne reguły panują jednak w obrębie zjawiska, które można nazwać polskim kiczem religijnym po Zagładzie.

\section{Przegląd materiału i propozycja jego systematyzacji}

Za pomocą kategorii holokaustowego kiczu religijnego warto analizować zarówno literaturę czy sztukę, jak i dyskurs akademicki. Typologia zaproponowana w dalszej części artykułu została opracowana na podstawie kilkunastu współczesnych polskich powieści i opracowań podejmujących problematykę Zagłady. Ma ona układ problemowy i wskazuje na wątki i tematy najczęściej występujące w tych tekstach. Niektóre z nich wynikają z problematyki teologicznej obecnej w rodzimych pracach zbiorowych, inne odpowiadają refleksji na temat roli Kościoła i zakonów żeńskich w ukrywaniu dzieci w czasie wojny.

Oto lista tematów nasuwających się badaczowi po lekturze prozy Katarzyny Banachowskiej-Jaśkiewicz (Niepamięć, 2007; Ogród Króla Agrestów, 2012), Zbigniewa Białasa (Rutka, 2018), Piotra Czakańskiego (Zimno, 2006), Wojciecha Dutki (Czerń i purpura, 2013), Radosława Kobierskiego (Ziemia Nod, 2010), Roberta Rienta (Duchy Jeremiego, 2017), Ericha-Emmanuela Schmitta (Dziecko Noego, 2004, wyd. pol. 2009) ${ }^{35}$ oraz Ireneusza Wawrzaszka (Romeo i Julia z KL Auschwitz, 2017) ${ }^{36}$ :

1. teodycea,

2. Zagłada jako kara za żydowskie grzechy,

3. chrystianizacja Zagłady,

4. chrześcijańskie antecendencje Zagłady,

5. pobożność jako sposób jej symplifikacji,

6. dobry ksiądz,

7. pierwsza komunia żydowskich dzieci,

8. Holokaust i chrześcijański sens cierpienia,

9. Zagłada i aborcja.

${ }^{35}$ Zasadność włączenia tej zagranicznej powieści do zespołu analizowanych tekstów zostanie wytłumaczona dalej, podobnie jak ilustracja zagadnienia kiczu religijnego za pomocą piśmiennictwa w języku polskim.

${ }^{36}$ Poniższy przegląd ujęć tej tematyki jest, siłą rzeczy, wybiórczy i nie uwzględnia wszystkich zauważonych problemów. 
Najpoważniejszym, a zarazem najczęściej spotykanym problemem literatury o Zagładzie podejmującej refleksję religijną jest bez wątpienia teodycea w jej najbardziej rozpoznawalnej i charakterystycznej postaci, inwokowanej pytaniem, gdzie podział się Bóg w Auschwitz. Nagromadzenie takich wątpliwości można spotkać przede wszystkim w Czerni i purpurze Dutki, powieści rozgrywającej się prawie wyłącznie w KL Auschwitz-Birkenau:

Do tej pory wierzyła, że więźniowie cierpią przez karę Boga. Dotyczyło to szczególnie Żydów, którzy zdradzili przecież Jehowę. Elfride wierzyła, że Jehowa za dobro nagradza, a za zło karze. Ale w Auschwitz przekonała się, że zło jest bezkarne i że żaden ze zbrodniarzy nie został przez Wszechmogącego postawiony do karnego raportu [...]. Widziała przecież codziennie, że Niebo milczało, oglądając te niesamowite i z niczym nieporównywalne zbrodnie. Elfride postanowiła, że swoim czynem [późniejsze zabicie Niemki, będącej podobnie jak Elfride świadkiem Jehowy - M.T.] zakrzyczy ciszę Nieba ${ }^{37}$.

Ściśle powiązana z problemem teodycei wydaje się fantazja proponująca fabularyzowaną wersję „przygód” Chrystusa w Auschwitz. Snuje ją za To Mend the World. Foundation of the Future Jewish Thought Emila L. Fackenheima Piotr Weiser w artykule Kryzys czy koniec powszechności Kościoła, głoszq̨cego odkupienie, witającego pomazańca?:

Chrystus nie musiał, ale chciał cierpieć. Do bydlęcego wagonu, do komory gazowej zostałby jednak zagnany przemocą. Zapytania namiestnika zastąpiłyby zarządzenia komendanta. Piłat i Höss określają dwa różne światy, symbolizujące śmierć bezsensowną i śmierć odkupieńczą. Wierność Ojcu i zaufanie Ojca sprawiało, że Chrystus akceptował kolejne odsłony dramatu. Dorosły Chrystus, powracając na ziemię albo przychodząc na świat w czasach i w miejscu Zagłady, poszedłby do Auschwitz i bez wahania, i bez wyboru ${ }^{38}$.

Jeszcze bardziej problematyczny - przede wszystkim z powodu zastosowanej retoryki, skłonności do skrótu myślowego, efektownej pointy czy pars pro toto - wydaje się kolejny komentarz Weisera, realizujący z naddatkiem założenia kiczu:

Trzecia Rzesza nie zajmowała się wiernością i zaufaniem swoich ofiar, ale ich urodzeniem. Nie stwarzała ofiary, ale rozgniatała insekta. Bóg-Żyd, skazany na los ludzi-Żydów, przyszedłby na świat albo powróciłby na ziemię bez możliwości męczeństwa. Fackenheim uważał, że odkupienie zależało od czasu i miejsca. Mogło ono dokonać się na Golgocie, nie mogło dokonać się, powiedzmy, na Majdanku' ${ }^{39}$.

\footnotetext{
${ }^{37}$ Wojciech Dutka, Czerń i purpura, Warszawa: Wydawnictwo Albatros, 2013, s. 292.

${ }^{38}$ Piotr Weiser, Kryzys czy koniec powszechności Kościoła, głoszq̨cego odkupienie, witającego pomazańca? [w:] Holokaust a teodycea..., s. 167.

${ }^{39}$ Ibidem.
} 
Do motywu Zagłady jako kary spadającej na Żydów powraca Radosław Kobierski w powieści Nod, poświęconej m.in. historii getta w Tarnowie. Jak podaje autor, hebrajskie „nod” oznacza „błądzić”, i wedle jego słów przedstawia społeczność żydowską jako jeden wielki, niezróżnicowany, religijny naród, uzależniony od woli Boga i dokonujący zwykle nietrafionych wyborów:

Całe życie trapiło mnie to jedno pytanie: czy od nas cokolwiek zależy? Może wszystkie karty zostały rozdane, a my tylko się szarpiemy, błądzimy w ciemnościach? [...] Życie, to prawdziwe życie, takie jakie znamy, to, które stało się naszym udziałem, rodziło się na wygnaniu, w ziemi Nod, na pustyni Beer-Szeby. Jesteśmy kozłem Azazela, Anno [...]. A ja się pytam: jak długo będziemy pokutować za coś, czegośmy nie zrobili?"40.

Szczególnie ciekawa na tym tle wydaje się, wielokrotnie przetwarzana w kulturze, postać księdza katolickiego ratującego Żydów. Ma ona zupełnie inną wymowę niż analogiczne refleksje poświęcone siostrom zakonnym. Ksiądz, a szczególnie proboszcz zdają się uosabiać Kościół i legitymizować jego politykę oraz wybory, urastając przy tym do rangi Sprawiedliwych, i jednostronnie, nieraz wręcz niezgodnie z prawdą historyczną, symbolizując współczesny stosunek Kościoła do jego roli w wojennej przeszłości. Jej chybioną, zafałszowaną wersję przedstawiła w kontrowersyjnej pracy Dzieci żydowskie w klasztorach Ewa Kurek, która twierdzi, że polskie społeczeństwo nie było w żaden sposób przygotowane do udzielania Żydom pomocy (nie należy go więc z powodu braku tejże surowo rozliczać), jako priorytet traktowało obronę własnej państwowości. Dlatego w każdym geście Polaków zmierzającym do poprawy sytuacji obywateli żydowskich należy dziś widzieć nadludzki wysiłek i bezwzględnie go docenić. Polski kler angażował się w ratowanie „najbardziej zagrożonych: ukrywających się przed Niemcami żołnierzy i działaczy podziemia oraz Żydów polskich i ich dzieci"41. Taki obraz księży przedstawia też Katarzyna Banachowska-Jaśkiewicz, która w obu swoich powieściach zajmuje się wojenną historią Wadowic i miejscowych Żydów. W zakończeniu Niepamięci Maria Silberman, która przeżyła jako dziecko w Wadowicach wojnę m.in. dzięki pomocy księdza, stawia dobrze znane pytanie: „Czy w Oświęcimiu też był Bóg? Czy był tam, kiedy oni umierali?”42. Słyszy na nie odpowiedź proboszcza: „Ja wierzę, że Bóg jest i w Oświęcimiu"43.

Na początku lat czterdziestych wadowiccy parafianie planują pogrom antyżydowski. Otrzymują wsparcie księdza z sąsiedniej parafii, odwołującego się do

${ }^{40}$ Radosław Kobierski, Ziemia Nod, Warszawa: W.A.B., 2010, s. 384.

${ }^{41}$ Ewa Kurek, Dzieci żydowskie w klasztorach. Udział żeńskich zgromadzeń zakonnych w akcji ratowania dzieci żydowskich $w$ Polsce w latach 1939-1945, Lublin: Wydawnictwo Clio, 2001, s. 40.

${ }^{42}$ Katarzyna Banachowska-Jaśkiewicz, Niepamięć, Kraków: Wydawnictwo WAM, 2007, s. 302.

${ }^{43}$ Ibidem, s. 302. 
„poczucia sprawiedliwości i krwi wołającej o pomstę do nieba”44. W tym samym czasie ich własny proboszcz, ten sam, który będzie później rozmawiać z Marią, prowadzi zupełnie inną politykę i odprawia mszę w intencji pokoju. Narrator legitymizuje jego działania za pomocą obrazów unoszonej w górę błyszczącej monstrancji.

Zestawienie antagonistycznych postaw kleru, tak częste w powojennej kulturze polskiej, znacznie rzadziej pojawia się w narracjach zagranicznych. Zupełnie inną postawę księdza katolickiego przypomina w Dziecku Noego znany polskim czytelnikom przede wszystkim jako autor Oskara i pani Róży francuski pisarz Eric-Emmanuel Schmitt ${ }^{45}$. Działający w czasie wojny w Belgii ojciec Pons prowadził dom dla sierot. Część jego mieszkańców stanowiły dzieci bogatych żydowskich mieszczan. Wśród nich znajduje się Joseph, kilkuletni chłopiec, wychowany przez niewierzących rodziców. Jego nowy opiekun okazuje się osobą bezgranicznie oddaną wszelkiej wierze, szczególnie religiom społeczeństw ginących. Gdyby nie eklektyzm i kiczowatość tych działań, można by powiedzieć, że ojciec Pons to największy antropolog wśród wszystkich europejskich księży ratujących w czasie wojny Żydów. Tymczasem on sam o sobie mówi „Noe”, przedstawiając bohatera Starego Testamentu jako pierwszego w dziejach, działającego z woli Boga kolekcjonera, pomagającego przetrwać zagrożonym kulturom. Belgijski Noe w podziemiach swojej świątyni tworzy podziemną synagogę z setkami książek, zwojem Tory, modlitewnikami, mistycznymi poematami i świecznikami. Sam tak wyjaśnia, co nim kieruje: „W dzieciństwie mieszkałem w belgijskim Kongo, gdzie ojciec był urzędnikiem; biali tak bardzo gardzili czarnymi, że zgromadziłem kolekcję miejscowych wyrobów [...]. Obecnie prowadzę dwie kolekcje: cygańską i żydowską. Zbieram wszystko, co Hitler chce unicestwić" ${ }^{\prime 6}$.

Warto zauważyć, że Pons kolekcjonuje przede wszystkim rzeczy kosztowne, w czym nie różni się specjalnie od urzędników pracujących na rzecz Trzeciej Rzeszy. Z powieści wprawdzie nie wynika, żeby był kolaborantem, ale przynajmniej jedna scena, niespodziewanych odwiedzin hitlerowców w sierocińcu, świadczy o tym, że belgijski ksiądz potrafi z nimi nawiązać skuteczny dialog. Najbardziej osobliwa jest agitacja religijna. W przeciwieństwie do polskich sióstr zakonnych, o których pisała Kurek, ojciec Pons uczy niereligijnych Żydów judaizmu w przekonaniu, że w ten sposób wypełnia Boże posłannictwo, wedle którego Żydzi mimo Zagłady (a może właśnie dzięki niej) dalej mają być narodem wybranym.

Także w tej powieści najczęstszą barwą katolicyzmu jest złoto i to ono, a nie Bóg, ludzie czy ich uczucia, staje się obiektem szczególnego wzruszenia narra-

${ }^{44}$ Ibidem, s. 123 .

${ }^{45}$ Warto dodać, że jest to powieść poświęcona „pamięci księdza André, wikarego parafii Świętego Jana Chrzciciela w Namur, i wszystkich Sprawiedliwych wśród Narodów Świata” (Eric-Emmanuel Schmitt, Dziecko Noego, tłum. Barbara Grzegorzewska, Kraków: Wydawnictwo Znak, 2009, s. 5).

${ }^{46}$ Ibidem, s. 68. 
tora. W scenie oglądania przez chłopców obrazka Matki Bożej przedstawia się to następująco:

Wodziłem palcem po cennej chuście okalającej spokojną twarz. Muskałem złoto. Gładziłem głowę Matki Boskiej. A ona mi na to pozwalała. Niespodziewanie łzy napłynęły mi do oczu i osunąłem się na ziemię. Rudi też. Płakaliśmy cicho z obrazkami od komunii przyciśniętymi do serca. Każdy myślał o swojej matce. Gdzie jest? ${ }^{47}$

Jednak dopiero $\mathrm{w}$ dwu powieściach polskich autorów, z których jeden jest związany z Kościołem katolickim (Czakański), drugi zaś z kwestionującymi jego zasady związkami wyznaniowymi (Rient), religijny kicz holokaustowy zyskał wyraźny, ciekawy badawczo wymiar. Zimno Czakańskiego stanowi fantazję na temat losów siódmego z Ulmów, Józefa-syna, urodzonego „w grobie”"48. Autor powieści, przez długie lata pracujący w radiu eM, popularyzującym wiedzę na temat Kościoła i archidiecezji katowickiej i jednocześnie zaangażowany w tworzenie festiwalu żydowskiego na krakowskim Kazimierzu, napisał przypominające dokument osobisty wspomnienia umierającego dorosłego Józefa-syna, który wraca pamięcią do marca 1944 r. i zabójstwa najbliższej rodziny oraz lat powojennych, spędzonych głównie w Austrii. Już pierwszy rozdział, zatytułowany Kwiecień, ujawnia tę cechę narracji, która będzie pojawiać się w Zimnie do końca. Jest nią splot wątków religijnych (najczęściej modlitw) z fanatycznymi wręcz, nastawionymi na obronę Kościoła, antykomunizm i pochwałę postaw konserwatywnych refleksjami bohaterów. Można w tym zobaczyć niedostosowanie i nagromadzenie, dwie cechy przypisywane kiczowi przez Gabrielę Żuchowską ${ }^{49}$. Na przykład tuż przed morderstwem Ulmów chłopi mijają przydrożny krzyż i nucą melodię Kiedy ranne wstaja zorze; po zabójstwie Goldmanów Józef Ulma ojciec recytuje Psalm 91. Następnie, po zabójstwie jego i rodziny, chłopi wykopują dwa groby:

Do jednego dołu Żydów, do drugiego katolików, by móc płakać i odmawiać swoją modlitwę nad grobem... Jizkor Elohim Niszmat, a potem Stanę przed Stwórcq i przed swoim Bogiem... Nie jesteśmy zwierzętami, mamy tradycje. Bezdomny dziad niech gra, niech głośno gra, by zagłuszyć mój pierwszy krzyk. I potem szybko na probostwo, do ciepłej kuchni. A kucharka tylko płacze, Boże drogi. Będę żył ${ }^{50}$.

${ }^{47}$ Ibidem, s. 52 .

${ }^{48}$ Piotr Czakański, Zimno, Katowice: Wydawnictwo FA-art, 2006, s. 11. Tym mocnym, paradoksalnym zwrotem („urodziłem się w grobie”) Czakański otwiera autobiografię ostatniego z Ulmów, być może najbardziej dosłownie rozumianego pogrobowca, jakiego mogła wymyślić kiedykolwiek literatura.

${ }^{49}$ Żuchowska, Kicz..., s. 140.

${ }^{50}$ Czakański, Zimno..., s. 17. 
Równie emocjonalne i sugestywne wydaje się zakończenie powieści, w którym ciężko chory bohater oddaje się marzeniom o śmierci: planuje wraz z włożeniem swojego ciała do trumny umieszczenie w niej obrazka Maryi z sanktuarium w Piekarach Śląskich, odśpiewanie przez kantorów pieśni Do domu wracam, jak strudzony pielgrzym..., pochówek w kwaterze sąsiadującej z grobem Żydów („bo wracam do domu”51) oraz różaniec („będę słyszał głuche słowa szczerej modlitwy różańcowej, intonowanej przez wieśniaków za spokój duszy wymordowanych rodzin [Ulmów, Goldmanów i Szallów, którym dedykowana jest powieść - M.T.]"52. Punktem kulminacyjnym wspomnianej narracji jest jednak rozdział Rodzice, poświęcony prawie w całości Wiktorii Ulmowej i jej kalectwu, za którego sprawą - fantazjuje bohater - po wojnie zarzucano by jej nadmierne oddanie się misji macierzyństwa oraz bycie żywym wzorem dla ruchów pro life:

Już słyszę te komentarze dzisiaj, że paralityczka rodzi siódme dziecko. A b o r terzy mieliby swój żer [wyróżnienie moje-M.T.]. A ojciec by musiał być dla nich niezłym dewiantem. Zrobił mnie kobiecie po ciężkim wylewie.

„Pieprzę was wszystkich. Zostawcie rodziców w spokoju” - darłbym się na cały szkolny korytarz. Potem za kudły na głowie dorwałbym synalka aktywisty partyjnego, wciągnął do opustoszałej już klasy i strzelił tą sowiecką gębą o kant krzesła. Niech pluje krwią. Nie ma zmiłuj się! Tak walić w czerwony ryj potrafią tylko ministranci ${ }^{53}$.

Dyskurs antyaborcyjny w powieści o Zagładzie, zwłaszcza tak naszpikowany odwołaniami do sceny dokonania wspólnego mordu na Polakach i Żydach, należy uznać za przejaw „holokaustyzacji”. „Ten typ dyskursu - pisał w Młynach bożych Jacek Leociak - rozwijają w Polsce przede wszystkim świeckie środowiska narodowo-katolickich fundamentalistów, ale doktrynalne podstawy zbudowały tu wypowiedzi najwyższych hierarchów Kościoła rzymskokatolickiego z papieżem Janem Pawłem II na czele" 54 .

Fanatyzm religijny połączony z dewiacyjną osobowością narratora-samotnika, który urodził się w samym środku Zagłady, sprawia, że Zimno trudno byłoby nawet katolikowi przeczytać bez zdziwienia na twarzy.

Innym przykładem religijności operuje w Duchach Jeremiego Robert Rient. Jego powieść to przykład kumulacji kiczu holokaustowego, będącej efektem ukazania konsekwencji Zagłady dla życia trzech pokoleń Żydów ${ }^{55}$. Pojawiają się w niej duch babki Żydówki, która przeżyła getto warszawskie, ale później popełniła samobójstwo, jej mąż, sybirak, niemowa, chory na Alzheimera, ich córki:

\footnotetext{
${ }^{51}$ Ibidem, s. 74 .

${ }^{52}$ Ibidem.

${ }^{53}$ Ibidem, s. 48.

${ }^{54}$ Jacek Leociak, Młyny boże. Zapiski o Kościele i Zagładzie, Wołowiec: Czarne, s. 185-186.

${ }^{55} \mathrm{Na}$ ten temat zob. recenzję Wojciecha Szota, https://www.kurzojady.pl/867-robert-rient-duchy-jeremiego (dostęp 28 IV 2019 r.).
} 
śmiertelnie chora na raka matka głównego bohatera i jego ciotka, lesbijka, buddystka, oraz tytułowy Jeremi, nastolatek, który na oczach czytelnika odkrywa, że jest Żydem ${ }^{56}$. Wykładnię teodycei, zrozumiałej - zdaniem Rienta - dla zbuntowanego dwunastolatka, przedstawia w postaci banalnej katechezy ciotka Estera. Efekt jej starań jest zdumiewający. Jeremi odkrywa, że pytania w rodzaju „Jest Bóg, czy go nie ma? Chce, żebyśmy chorowali, czy nie chce?"57, są bardzo proste w przeciwieństwie do analogii między Biblią a Zagładą (których źródłem jest dla chłopca Księga Estery: „[...] nie bardzo rozumiałem, dlaczego [Bóg - M.T.] pomógł Żydom wtedy, a już całkiem niedawno rodzinie babci i innym to nie pomógł" ${ }^{58}$ ). Za sprawą tego typu infantylizacji autor czyni Zagładę jedną z największych chorób XX i XXI w., na którą, podobnie jak na raka, nie ma lekarstwa, ale o uzdrowienie z niej warto się modlić: „Te moje komórki są specyficzne, mówi się o nich, że są agresywne. - Jak gestapowcy? - Jak gestapowcy"59.

\section{Chrystianizacja Zagłady}

Zgodnie z założeniami przedstawionej tu koncepcji najbardziej zideologizowane przykłady kiczu przynoszą powieści autorów świadomych rzemiosła i swoich zadań. Wydaje się, że powinni oni również wiedzieć, iż chrystianizując Zagładę, zdają kłam historii. Realizują bowiem określoną politykę historyczną i jednocześnie prezentują własne dewiacje oraz fantazje. Gdyby chciało się rozpatrywać prozę, o której mowa dalej, na tle szerszego kontekstu kulturowego, należałoby odnieść się do uwag George’a Steinera z eseju Sezon w Piekle. Autor Po wieży Babel zaproponował interpretację Zagłady jako Drugiego Upadku oraz „dobrowolnego odejścia z Edenu i programowej próby spalenia go za sobą"60, poddając refleksji jej ukryty religijny charakter, tożsamy z poszukiwaniami odpowiedzi na pytanie o przyczyny dominacji w Europie chrześcijaństwa z jego niemożliwym do udźwignięcia przez wiernych monoteizmem. W opinii Steinera obozy koncentracyjne przypominały przede wszystkim Dantejskie piekło skrzyżowane z wyobraźnią markiza de Sade’a. Były zatem czymś skrajnie estetycznym, odległym od rzeczywistości i przede wszystkim zbyt łatwym do zrozumienia. Można by nawet rzec, że w polityce Hitlera, która miała według eseisty doprowadzić do kresu chrześcijaństwo, zrealizowało się oczekiwanie

\footnotetext{
${ }^{56} \mathrm{Na}$ funkcję tego typu kumulacji zwróciła uwagę Agnieszka Haska, powołując się na artykuł Franka Furediego Fake Holocaust memoirs: history as therapy: „Czy nie jest tak, że w kulturze popularnej mamy do czynienia ze swoistą «licytacją na traumy», a trauma Zagłady jest tu wysoko punktowana?" (Agnieszka Haska, Zapętlenia pamięci i wyobraźni. Trzy opowieści o Zagładzie, „Zagłada Żydów. Studia i Materiały” 2010, nr 6, s. 53).

${ }^{57}$ Robert Rient, Duchy Jeremiego, Warszawa: Wielka Litera, 2017, s. 104.

${ }^{58}$ Ibidem, s. 142.

${ }^{59}$ Ibidem, s. 138.

${ }^{60}$ George Steiner, Sezon w Piekle [w:] idem, W zamku Sinobrodego. Kilka uwag w kwestii przedefiniowania kultury, tłum. Olga Kubińska, Gdańsk: Wydawnictwo Atext, 1993, s. 55.
} 
wielu chrześcijan na zobaczenie inferna i wydobycie go „spod ziemi na powierzchnię" 61 .

Powieści historyka Wojciecha Dutki ${ }^{62}$ (Czerń i purpura) oraz literaturoznawcy Zbigniewa Białasa ${ }^{63}$ (Rutka), nawiązując do przewrotnej i kontrowersyjnej, a w pewnych miejscach nawet kiczowatej myśli Steinera ${ }^{64}$, nie wywołały żadnego negatywnego odzewu (w przeciwieństwie do książek Czakańskiego czy Rienta). Otrzymały natomiast wiele entuzjastycznych recenzji, stając się przy-

${ }^{61}$ Ibidem, s. 63-64. Uzupełnieniem rozważań Steinera jest znakomity esej Pawła Śpiewaka Szoah, drugi upadek, opublikowany w formie wstępu w miesięczniku „Więź” w 1986 r. Nawiązując do słów amerykańskiego eseisty zacytowanych w niniejszym artykule, Śpiewak jeszcze mocniej zaznacza kwestię, jakoby Europa z Hitlerem na czele widziała w Zagładzie wydarzenie, które musiało nadejść, prowadzące do uwolnienia starych religii i końca chrześcijaństwa, któremu na drodze stali tylko Żydzi. Dlatego Zagłada była długo przygotowywanym uderzeniem, poprzedzonym falami nienawiści i antysemityzmu. A w końcu, gdy nastąpiła, całkowicie odizolowała społeczeństwo ofiar od wszystkich tych, którzy ofiarami - w najściślejszym sensie - nie byli. Proroctwo Nowego Testamentu, że oto zdarzenie miało się dokonać (jak śmierć Chrystusa na krzyżu), niezależnie od tego, czy jego szczegółową treść chciałoby się łączyć z wygnaniem Adama i Ewy z Raju, czy z oczekiwaniem na ponowne przyjście Zbawiciela, w opinii autora Żydokomuny doprowadziło przede wszystkim do zamilknięcia niebios. Po tym słyszalne zaczęły być „stukot wojny i miarowa praca fabryk śmierci” (Paweł Śpiewak, Szoah, drugi upadek, „Więź” 1986, nr 7/8, s. 13). Wyobraźnia polskiego socjologa nie wykroczyła więc poza dobrze nam znaną z dokumentów sferę audialną związaną z katorżniczą pracą. Nie przyczyniła się też do powstania wątpliwego etycznie obrazu o reinkarnacji Dantejskiego piekła w Auschwitz.

${ }^{62}$ Autor prowadzi bloga „Z Bielskiego sztambucha_Wojciech Dutka”, poświęconego „historii - w szczególności historiografii i literaturze, i filmowi”, http://wojciechdutka-piszecomysle.blogspot.com/ (dostęp 29 IV 2019 r.). Z biogramu pisarza, opublikowanego na jego oficjalnej stronie, wynika, że artykuły naukowe, w większości poświęcone powstaniu styczniowemu i historii Kościoła, ogłaszał w takich pismach jak „Kwartalnik Historyczny”, „Sensus Historiae. Studia Interdyscyplinarne”, „Klio”, „Niepodległość i Pamięć”, „Przegląd Humanistyczny”. Jest także autorem publikacji Żydzi w historiografii i piśmiennictwie rocznicowym powstania styczniowego w latach 1864-1918. Próba charakterystyki („Kwartalnik Historii Żydów” 2008, nr 2 (226), s. 144-151). W 2014 r. na podstawie rozprawy „Historia w dziełach i pismach Stanisława Koźmiana (1836-1922)" otrzymał stopień doktora nauk humanistycznych na Wydziale Historycznym Uniwersytetu Jagiellońskiego.

${ }^{63}$ Zbigniew Białas jest profesorem nauk humanistycznych specjalizującym się w literaturze postkolonialnej, a także w twórczości Johna Maxwella Coetzeego (był laudatorem w procesie nadania nobliście przez Uniwersytet Śląski tytułu doktora honoris causa). Był stypendystą Fundacji Alexandra von Humboldta, Fundacji Fulbrighta, Fundacji Rockefellera. Pracuje na Uniwersytecie Śląskim. Jest autorem powieści Korzeniec, Puder i pył, Tal oraz reportażu Nebraska. W 2018 r. wydał powieść Rutka. Zob. na ten temat Marta Tomczok, „Polecieć tam, gdzie nie ma getta, szopu...” Dziennik Rutki Laskier między nekroestetykq a nekropolityka, „Zagłada Żydów. Studia i Materiały" 2018, nr 14, s. 421-439.

${ }^{64}$ Warto dodać, że geneza pomysłu omówionego przez eseistę w Sezonie $w$ Piekle jest właściwie taka sama jak wielu teologów chrześcijańskich i żydowskich i stanowi „próbę zrozumienia, wyartykułowania przypadkowych i teologicznych aspektów Holocaustu" (Steiner, Sezon w Piekle..., s. 41-42). 
kładem literatury służącej - jak kicz - uspokajaniu i „uprzytulnianiu” świata, a nie przypominającej mu o rozpadzie wiary i umieszczeniu przez hitlerowców piekła na ziemi ${ }^{65}$. Ich autorom nie sposób wprost zarzucić żadnej „niewłaściwej” ideologii, podtrzymywanej i rozwijanej w pracach naukowych, publicystyce, wywiadach. Jedynym (za to wystarczająco mocnym) śladem ideologizacji uprawianego przez Białasa i Dutkę kiczu są ich powieści. W obu pojawia się ten sam typ reprezentacji krematorium jako miejsca sprzyjającego przemianie sprawców, obserwatorów i narratora w chrześcijan ${ }^{66}$.

Scena z Czerni i purpury jest krótka i opatrzona niezwykle wymownym komentarzem. Bohater powieści Franz Weimart, niegdyś gorliwy katolik, później fanatyczny esesman w Auschwitz, nadzoruje transport Żydów z Holandii, wśród których znalazły się dwie karmelitanki (jedną z nich jest Edyta Stein). Weimert odprowadza je do krematorium, czując, że ich obecność oddziałuje na niego w niezwykły, niewytłumaczalny wręcz sposób:

Cały ludzki język był już niepotrzebny, a głos starych biblijnych ksiąg, w który niegdyś wierzył, zamienił się $\mathrm{w}$ syk pradawnego węża, pełzającego $\mathrm{w}$ pyle i prochu ziemi. Franz, postawiony naprzeciw zakonnicy przy wejściu do komory gazowej, znalazł się tym samym na krawędzi piekielnej otchłani. Jej wzrok stał się ostatnią barierą, która odgradzała go od nicości [...]. Kiedy karmelitanka znalazła się już w drzwiach prowadzących do wnętrza komory gazowej, raz jeszcze się odwróciła [...]. I znów popatrzyła na niego ${ }^{67}$.

Następstwem tej sceny jest głęboka, wewnętrzna przemiana bohatera, pod której wpływem Weimert wiąże się z Żydówką uwięzioną w Auschwitz i zaczyna pomagać Żydom.

W Rutce do komory gazowej żałosnym wzrokiem odprowadza tytułową bohaterkę pies esesmana. Wcześniej, w postaci podobnego jak wyżej komentarza odautorskiego, pojawia się wyobrażenie dialogu toczącego się między Rutką Laskier a anonimowym rebem na temat obmywania wodą martwych żydowskich ciał. Ponieważ w obozie nie jest to możliwe, rebe odpowiada dziewczynie: „Ogień bowiem oczyszcza jeszcze lepiej niż woda"68, odwołując się do mistycznych właściwości żywiołu, a także do kontrowersyjnego źródłosłowu terminu „holokaust” ${ }^{69}$.

\footnotetext{
${ }^{65}$ Ibidem, s. 65.
}

${ }^{66}$ Oba przypadki warto rozpatrywać w kontekście uwag Friedländera i Alvina H. Rosenfelda na temat nieprzystawalności metarefleksji takich autorów jak Leslie Epstein czy George Steiner, krytykujących wszelką fikcję na temat Zagłady, przy czym warto zauważyć, że ci ostatni w swojej późniejszej twórczości artystycznej wyraźnie łamią zakazy, o których wcześniej pisali (The Portage to San Cristóbal of A.H. Steinera czy Król Żydowski Epsteina) (Friedländer, Refleksy nazizmu..., s. 97).

${ }^{67}$ Dutka, Czerń i purpura..., s. 265.

${ }^{68}$ Zbigniew Białas, Rutka, Kraków: Wydawnictwo MG, 2018, s. 124.

${ }^{69}$ „Nie tylko termin ten zakłada niedopuszczalne zrównanie pieca krematoryjnego z ołtarzem, lecz obarczone jest semantycznym dziedzictwem od samego zarania nacechowanym antyżydowsko. [...] Ten, kto nadal go używa, daje świadectwo własnej niewiedzy albo całko- 
Z kolei nagie martwe ciało interpretuje w kontekście Biblii jako powrót do postaci nowo narodzonego dziecka. W myśl tej wykładni Auschwitz stwarza warunki do dosłownej realizacji znanych biblijnych powiedzeń w rodzaju: „Z prochu powstałeś, w proch się obrócisz", a zatem - odwołując się do komentowanych wcześniej wywodów Fackenheima i Weisera - w ostatecznym rozrachunku okazuje się miejscem uświęcenia ofiar i chrystianizacji Zagłady.

W tej dość oczywistej interpretacji powinno się jednak znaleźć miejsce na odczytanie motywu mniej zrozumiałego, a pojawiającego się w obu scenach - odprowadzania wzrokiem ofiar zmierzających do krematorium. Do kogo naprawdę on należy i czego oczekuje (od czytelnika)? Odkupienia? Przyciągnięcia uwagi? Rozgrzeszenia? Jeśli przyjmie się, że wspomniany wzrok należy do narratorów polskich powieści o Zagładzie, dywagujących na temat nawrócenia esesmanów w Auschwitz, to trzeba przyznać, że jest to wzrok symbolizujący przede wszystkim pragnienie oczyszczenia się z winy współsprawstwa - z polskich win wobec Żydów, którzy zginęli w Zagładzie. Ta daleko posunięta interpretacja, wykraczająca poza to, co oba teksty chcą bezpośrednio powiedzieć, zgadza się w najważniejszych punktach z definicją religijnego kiczu holokaustowego, zapośredniczoną w rozważaniach Klemperera. Bóg (bądź jego nieobecność) jest winien Zagładzie, ona sama natomiast służy(ła) jeszcze mocniejszemu wyróżnieniu narodu wybranego i sakralizacji ofiar. Przypisywany Zagładzie $\mathrm{w}$ polskich narracjach sens, nazywany tu chrystianizacją, z jednej strony ma charakter samousprawiedliwienia (to dobrze, że nie ratowaliśmy tych ludzi, bo dzięki temu prędzej znaleźli się u Boga), a z drugiej stwarza szansę na pokazanie Zagłady jako paruzji (by jeszcze raz przypomnieć wizje Weisera). W plan Boży ludziom nie wolno ingerować. Dlatego, zgodnie z tym, co napisała Kurek, powinni oni realizować inne priorytety i niekoniecznie pomagać. „Teologia Zagłady [...] - twierdził Yehuda Bauer - prowadzi donikąd"70. Religijny kicz holokaustowy stanowi wierne odwzorowanie tej ślepej ścieżki. Nie oznacza to wszakże, iż ślepe ścieżki są nieuczęszczane. Przeciwnie, kategoria kiczu wydaje się dziś, jak nigdy wcześniej, szczególnie często używana.

\section{BIBLIOGRAFIA}

Agamben Giorgio, Co zostało z Auschwitz. Archiwum i świadek (Homo sacer III), tłum. Sławomir Karolak, Warszawa: Wydawnictwo Sic!, 2008.

Banachowska-Jaśkiewicz Katarzyna, Niepamięć, Kraków: Wydawnictwo WAM, 2007.

Bauer Yehuda, Przemyśleć Zagładę, tłum. Jerzy Giebułtowski, Janusz Surewicz, Warszawa: ŻIH, 2016.

Beylin Paweł, Kicz jako zjawisko estetyczne i pozaestetyczne [w:] idem, Autentyczność i kicze, Warszawa: PIW, 1975.

witego braku wrażliwości (lub obu naraz)" (Giorgio Agamben, Co zostało z Auschwitz. Archiwum i świadek (Homo sacer III), tłum. Sławomir Karolak, Warszawa: Wydawnictwo Sic!, 2008, s. 30-31).

${ }^{70}$ Bauer, Przemyśleć Zagładę..., s. 274. 
Białas Zbigniew, Rutka, Kraków: Wydawnictwo MG, 2018.

Boswell Matthew, Holocaust Impiety in Literature, Popular Music and Film, London: Palgrave Macmillan, 2012.

Broch Herman, Kilka uwag o kiczu (Odczyt), tłum. Danuta Borkowska, Jan Garewicz, Ryszard Turczyn, Warszawa: Czytelnik, 1998.

Czakański Piotr, Zimno, Katowice: Wydawnictwo FA-art, 2006.

Dutka Wojciech, Czerń i purpura, Warszawa: Wydawnictwo Albatros, 2013.

Eaglestone Robert, The Broken Voice. Reading post-Holocaust Literature, Oxford: Oxford University Press, 2017.

Friedländer Saul, Refleksy nazizmu. Esej o kiczu i śmierci, tłum. Marcin Szuster, wstęp Paweł Śpiewak, Warszawa: WUW, 2011.

Haska Agnieszka, Zapętlenia pamięci i wyobraźni. Trzy opowieści o Zagładzie, „Zagłada Żydów. Studia i Materiały" 2010, nr 6.

Klemperer Victor, LTI. Notatnik filologa, tłum. Juliusz Zychowicz, Warszawa: Aletheia, 2014.

Leociak Jacek, Młyny boże. Zapiski o Kościele i Zagładzie, Wołowiec: Czarne, 2018.

Ngai Sianne, Our Aesthetic Categories: Zany, Cute, Interesting, Harvard: Harvard University Press, 2012.

Obirek Stanisław, Holokaust - problem Boga czy człowieka? [w:] Holokaust a teodycea, red. Jerzy Diatłowicki, Karolina Rąb, Iwona Sobieraj, Kraków: Wydawnictwo Homini, 2008.

Rient Robert, Duchy Jeremiego, Warszawa: Wielka Litera, 2017.

Rose Gillian, Mourning Becomes the Law. Philosophy and Representation, Cambridge: Cambridge University Press, 1996.

Saltzman Lisa, „Avant-Garde and Kitsch Revisited” [w:] Mirroring Evil: Nazi Imagery/Recent Art, red. Norman Kleeblatt, New York: The Jewish Museum i New BrunswickRutgers University Press, 2001.

Schmitt Eric-Emmanuel, Dziecko Noego, tłum. Barbara Grzegorzewska, Kraków: Znak, 2009.

Steiner George, W zamku Sinobrodego, przeł. Olga Kubińska, Gdańsk: Wydawnictwo Atext,1993.

Śpiewak Paweł, Kicz i estetyzacja polityki [w:] Saul Friedländer, Refleksy nazizmu. Esej o kiczu i śmierci, tłum. Marcin Szuster, wstęp Paweł Śpiewak, Warszawa: WUW, 2011.

Tiffany Daniel, My Silver Planet. A Secret History of Poetry and Kitsch, Baltimore: Johns Hopkins University Press, 2014.

Śpiewak Paweł, Szoah, drugi upadek, „Więź” 1986, nr 7/8.

Tomczok Marta, „Polecieć tam, gdzie nie ma getta, szopu...” Dziennik Rutki Laskier między nekroestetykq a nekropolityka, „Zagłada Żydów. Studia i Materiały” 2018, nr 14.

Ubertowska Aleksandra, Krzepiąca moc kiczu. Literatura Holokaustu na (estetycznych) manowcach, „Zagłada Żydów. Studia i Materiały” 2010, nr 6.

Weiser Piotr, Kryzys czy koniec powszechności Kościoła, głoszącego odkupienie, witającego pomazańca? [w:] Holokaust a teodycea, red. Jerzy Diatłowicki, Karolina Rąb, Iwona Sobieraj, Kraków: Wydawnictwo Homini, 2008.

Żuchowska Gabriela, Kicz - przegląd koncepcji teoretycznych i propozycja definicji do celów badawczych, „Kultura i Społeczeństwo” 2013, nr 1. 